\title{
VLADIMÍR ŠIMANSKÝ
}

Slovak University of Agriculture, Faculty of Agrobiology and Food Resources, Department of Soil Science

\section{ASSESSMENT OF SOIL STRUCTURE UNDER MONOCULTURE OF VINES}

\begin{abstract}
Long-term impact of vine growing on the soil structure stability was studied in three wine-growing areas of Slovakia. In Leptosols, the highest content of water-stable aggregates was determined. This soil type had the lowest vulnerability of soil structure as well. In Chernozems, the highest stability of soil structure was determined, while on the other hand, in Fluvisols, soil structure had the highest vulnerability. Between rows of vines in comparison to rows of vines a more favourable soil structure was determined. In vineyards, the soil structure state depends on the quantity and stability of soil organic matter, as well as particle size distribution.
\end{abstract}

Key words: soil structure stability, organic matter, water-stable aggregates, vineyard

\section{INTRODUCTION}

Soil structure is a key factor of soil quality, which plays an important role in forming favourable physical conditions for vine growing. It affects the provision of sufficient moisture physiologically available to plants, aeration and continuous release of nutrients in available forms. From point of view of soil structure, the aggregation processes and aggregate stability are very important (aggregate $=$ based of soil structure). Macro-aggregates are formed and stabilized by biological factors, such as roots and fungal hyphae and by products of microbial synthesis and decay [Tisdall and Oades 1982, Lado et al. 2004], on the other hand, micro-aggregates are more often formed and stabilized by chemical factors, such as clay mineralogy [Tisdall and Oades 1982, Six et al. 2004, Tobiašová and Horvátová 2010]. In topsoil, the ideal soil structure is formed by predominantly crumb-like aggregates, best formed when organic matter is naturally high ( $>2 \%$ organic carbon content) and well humified [Greenland et al. 1975]. The role of organic matter is less significant in the subsoil where the type of clay mineral and the exchangeable cations are more important [Bronick and Lal 2005]. Soil structure can be significantly regulated by soil management and environmental changes, especially in vineyards. Establishment of a vineyard is a complicated process. There is significant reshaping the natural soil environment. This process is reflected in the structure of soil and its stability.
The objective of this study was to evaluate the long-term impact of vine growing on the soil structure stability.

\section{MATERIAL AND METHODS}

During the years from 2006 to 2009, soil samples were collected from the top soils (to a depth of 0.3 $\mathrm{m})$ before grape-vine harvest in rows and between rows. Soil samples were taken from 4 localities in 3 wine growing areas (1. Dvory nad Žitavou, 2. Šoporňa, 3. Viničky, 4. Dražovce). Before sampling, on each locality were revived two pits (1. in rows of vine, 2. between rows of vine). Soils were classified according to WRB (FAO 2006) basing on whole-profile morphology (Dvory nad Žitavou - Haplic Chermozems, Šoporňa - Eutric Fluvisols, Viničky - Eutric Cambisols, Dražovce - Rendzic Leptosols). Some chemical characteristics and particle size distribution of the soil profiles $(0-0.3 \mathrm{~m})$ are given in Table 1 .

Soil samples were taken with the aid of a spade to maintain the soil in their natural aggregates. Soil samples were also air-dried at laboratory temperature, presieved over a series of sieves, and then bulked into seven size fractions. These size fractions (dry sieve) were used for determination of water-stable aggregates (WSA) [Hraško et al. 1962]. In size fractions of WSA, was determined organic carbon content (Corg) according to Tyurin method [Dziadowiec and Gonet 1999]. There were also calculated the structure coefficient $(\mathrm{K})$, vulnerability coefficient $(\mathrm{Kv})$ by Valla et 
TABLE 1 . Some chemical characteristics and particle size distribution in selected localities $(0-0.3 \mathrm{~m})$

\begin{tabular}{|c|c|c|c|c|c|c|c|c|c|c|c|c|c|}
\hline \multirow[t]{3}{*}{ Localities } & \multicolumn{2}{|l|}{$\begin{array}{l}\mathrm{CO}_{3}{ }^{2-} \\
{[\%]}\end{array}$} & \multicolumn{2}{|l|}{$\begin{array}{l}\text { Corg } \\
{[\%]}\end{array}$} & \multicolumn{2}{|c|}{$\mathrm{C}_{\mathrm{HA}}: \mathrm{C}_{\mathrm{FA}}$} & \multicolumn{2}{|l|}{$\mathrm{Q}_{\mathrm{HS}}$} & \multicolumn{2}{|l|}{$\mathrm{Q}_{\mathrm{HA}}$} & \multirow[t]{3}{*}{$\begin{array}{l}\text { Sand } \\
{[\%]}\end{array}$} & \multirow[t]{3}{*}{$\begin{array}{l}\text { Silt } \\
{[\%]}\end{array}$} & \multirow[t]{3}{*}{$\begin{array}{l}\text { Clay } \\
{[\%]}\end{array}$} \\
\hline & \multicolumn{10}{|c|}{ Soil management } & & & \\
\hline & rows & $\begin{array}{l}\text { between } \\
\text { rows }\end{array}$ & rows & $\begin{array}{l}\text { between } \\
\text { rows }\end{array}$ & rows & $\begin{array}{l}\text { between } \\
\text { rows }\end{array}$ & rows & $\begin{array}{l}\text { between } \\
\text { rows }\end{array}$ & rows & $\begin{array}{l}\text { between } \\
\text { rows }\end{array}$ & & & \\
\hline Dvory $n /$ Žitavou & 0.36 & 0.32 & 1.20 & 0.87 & 0.93 & 1.24 & 5.25 & 5.20 & 4.41 & 4.52 & 66 & 26 & 8 \\
\hline Šoporňa & 0.20 & 0.22 & 1.42 & 1.62 & 0.91 & 0.89 & 4.05 & 4.13 & 3.61 & 3.63 & 67 & 21 & 12 \\
\hline Viničky & - & - & 1.09 & 1.12 & 0.68 & 0.53 & 5.39 & 4.87 & 4.20 & 4.18 & 51 & 42 & 7 \\
\hline Dražovce & 1.35 & 1.25 & 1.58 & 1.52 & 0.88 & 1.01 & 4.62 & 5.50 & 4.04 & 4.27 & 57 & 33 & 10 \\
\hline
\end{tabular}

Explanations: $\mathrm{CO}_{3}{ }^{2-}-$ carbonates, Corg - organic carbon content, $\mathrm{C}_{\mathrm{HA}}: \mathrm{C}_{\mathrm{FA}}-$ carbon of humic acids to carbon of fulvic acids, $\mathrm{Q}_{\mathrm{HS}}-$ colour quotient of humic substances, $\mathrm{Q}_{\mathrm{Ha}}$ - colour quotient of humic acids.

al. [2000] as well as the stability index of water-stable aggregates (Sw) by Henin [Zaujec and Šimanský 2006] and values of sum of mean weight diameters (MWD) in fractions of aggregates. Multifactor analysis of variance (ANOVA) was used to determine differences between soil types and human activity (rows and between rows of vines). LSD test was used for evaluation of means when ANOVA results were significant at $P$ values $<0.05$. Correlation analysis to determine the relationships between chemical properties, soil organic matter (SOM), soil structure stability and quantity of SOM in size fractions of WSA were used.

\section{RESULTS AND DISCUSSION}

Content of water-stable macro-aggregates (WSAm) by sieving the soil sample over a set sieves (in distilled water) were determined. Portion of WSAm varied with dependence on soil type. According to the classification Dolgova and Bachtin [Sisak 1994], the favourable state means, water-stable macro-aggregates content in the range $40-55 \%$. Content of WSAm according to the criteria was higher than the upper limit of this range and varied in the range of 65.72 to $82.68(79.21 \pm 9.47) \%$. Karlen et al.
[1994] reported WSAm content ranging from 30 to $60 \%$, while a greater percentage of water-stable aggregates means to a more favourable condition of soil structure. In Leptosols $(87.74 \pm 5.46 \%$ ), the highest content of WSAm was recorded. Then follows, Chernozems $(82.68 \pm 7.47 \%)>$ Cambisols $(80.7 \pm 11.79 \%)$ and the lowest content of WSAm was recorded in Fluvisols (65.72 $\pm 26.76 \%)$.

Further parameters of soil structure with dependence on soil type are in Figure 1. After a comprehensive assessment of all evaluated parameters, in Chernozems the most favourable structural state was determined. There were the highest stability index values (2.29) and structure coefficient (6.98). On the other hand, there were the lowest differences between values of MWDs and MWDm and therefore the most favourable values of the coefficient of vulnerability (1.25). In Fluvisols, the lowest stability (1.46), but also structure coefficient $(0.87)$ was determined. The soil type was characterized by the highest value MWDs (4.97), but on the other hand, the lowest MWDm (0.39), and therefore had a high vulnerability of soil structure (13.78).

Significant effect on the aggregation process except soil type [Bronick and Lal 2005, Tobiašová

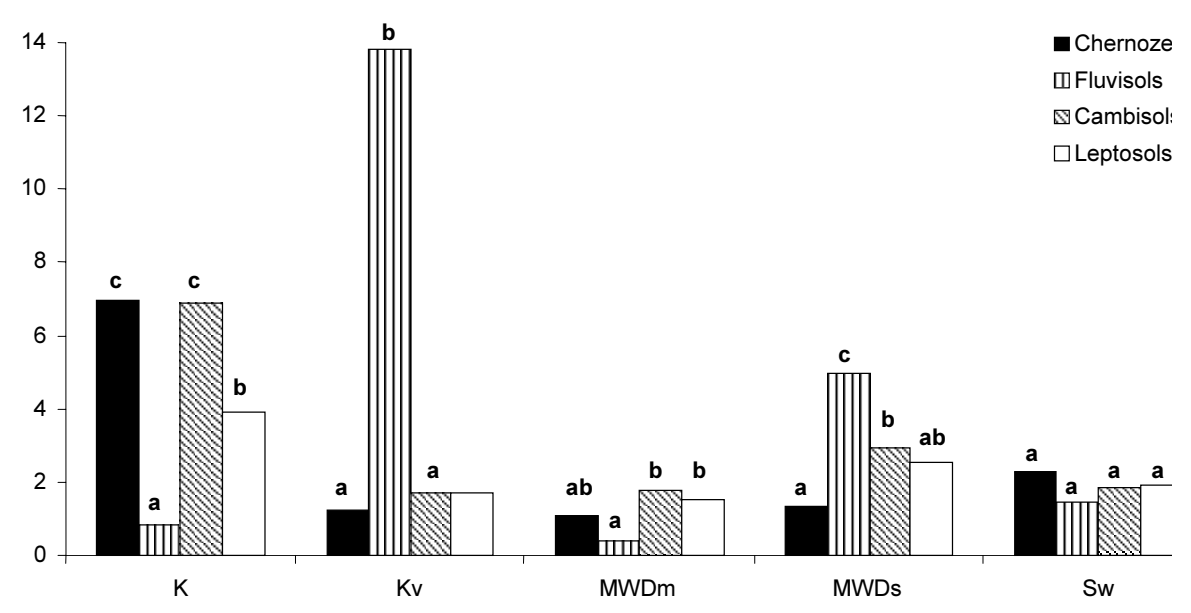

FIGURE 1. Parameters of soil structure with dependence on soil type:MWDs - mean weight diameter-dried sieved, MWDm - mean weight diameters of water-stable aggregates, $\mathrm{Sw}-$ index of stability, $\mathrm{K}$ - structure coefficient, $\mathrm{Kv}$ - index of vulnerability.

Different letters between columns of soil structure parameters $(a, b)$ indicate significantly different at $\mathrm{P}<0.05$ according to LSD multiple-range test 
TABLE 2. Parameters of soil structure stability with dependence on soil management in productive vineyards

\begin{tabular}{llrrrr}
\hline Parameters & $\begin{array}{l}\text { Soil } \\
\text { management }\end{array}$ & Min. & Max. & Average & $\begin{array}{c}\text { Standard } \\
\text { deviation }\end{array}$ \\
\hline WSAm & rows & 46.80 & 91.60 & 74.68 & 20.37 \\
& between rows & 77.40 & 89.04 & 83.74 & 4.80 \\
\hline MWDs & rows & 1.22 & 4.58 & 2.82 & 1.38 \\
& between rows & 1.49 & 5.36 & 3.08 & 1.68 \\
\hline MWDm & rows & 0.28 & 1.48 & 1.09 & 0.55 \\
& between rows & 0.49 & 2.17 & 1.31 & 0.72 \\
\hline Sw & rows & 1.30 & 2.45 & 1.75 & 0.58 \\
& between rows & 1.62 & 2.39 & 1.99 & 0.34 \\
\hline $\mathrm{K}$ & rows & 1.13 & 8.01 & 5.09 & 3.33 \\
& between rows & 0.60 & 6.28 & 4.25 & 2.57 \\
\hline $\mathrm{KV}$ & rows & 0.99 & 16.66 & 5.38 & 7.54 \\
& between rows & 1.44 & 10.85 & 3.82 & 4.69 \\
\hline
\end{tabular}

Explanations: WSAm - water-stable macro-aggregates, MWDs - mean weight diameter-dried sieved, MWDm - mean weight diameters of water-stable aggregates, $\mathrm{Sw}$ - index of stability, $\mathrm{K}$ - structure coefficient, $\mathrm{Kv}-$ index of vulnerability.

2011] has also soil management [Tobiašová and Šimanský 2009, Tobiašová 2010]. Aggregate dynamics depends on the intensity of cultivation, application of fertilizers [Šimanský and Tobiašová 2008], application of farmyard manure [Layton et al. 1993] crop rotation [Jarecki and Lal 2003], but also other anthropogenic factors. Parameters of soil structure with dependence on soil management in productive vineyards are shown in Table 2 . In between rows of vines (grown grass) compared with intensively cultivated rows almost all indicators of soil structure stability (except structure coefficient) showed a more favourable structure. One of the most important factors affecting the formation of aggregates is soil organic matter (SOM), which is involved in the stabilization of soil structure. In rows of vines due to intensive cultivation the loss of SOM was determined (Table 1) and this is reflected in worse structural state of soils (Table 2).

Aggregates are formed mostly by the action of humic substances on mineral particles. Increase of soil organic carbon is associated with increase of aggregation [Schulten and Leinweber 2000]. In soil, organic carbon content was in negative correlation with a structure coefficient. Between the stability of organic matter and soil structure parameters statistically significant correlation was observed (Table 3). Obtained results showed on fact that higher values of MWDs are reason increasing of humus stability. All the same, lower values of humus stability had positive effect on lower coefficient of vulnerability as well as on higher values of structure coefficient. It means that for favourable structural state in soils had except organic carbon content important role also humus stability. Very important factor influences of soil structure are soil texture fractions [Kay 1998], which was confirmed (Table 3). Between MWD, structure coefficient, coefficient of vulnerability and individual grain-size fractions statistically significant correlations were observed. Carbonate content in soils can increase aggregate stability in arid environment [BoixFayos et al. 2001. Between carbonate content and parameters of structure stability any correlations were observed (Table 3).

TABLE 3. Correlations between soil organic matter, particle size distribution, carbonate content and parameters of soil structure stability

\begin{tabular}{|c|c|c|c|c|c|c|}
\hline & WSAm & MWDs & MWDm & Sw & K & $\mathrm{Kv}$ \\
\hline & 0.378 & $-0.864^{* *}$ & 0.620 & 0.045 & $-0.857^{* *}$ & $0.852^{* *}$ \\
\hline & 0.454 & $-0.959^{* * *}$ & 0.601 & 0.243 & $-0.871^{* *}$ & $0.886^{* *}$ \\
\hline${ }_{\mathrm{HA}}^{\mathrm{HA}}: \mathrm{C}_{1}$ & -0.121 & -0.317 & -0.481 & 0.449 & -0.126 & 0.039 \\
\hline Corg & 0.069 & 0.589 & -0.268 & 0.133 & $-0.758 *$ & 0.433 \\
\hline Sand & -0.308 & 0.156 & $-0.814^{*}$ & 0.504 & -0.435 & 0.533 \\
\hline Sil & 0.357 & -0.312 & $0.867^{* *}$ & -0.437 & 0.594 & -0.651 \\
\hline Clav & -0.415 & $0.793^{*}$ & $0.734^{*}$ & 0.005 & $-0.960^{* * *}$ & $0.852^{* *}$ \\
\hline $\mathrm{CO}_{3}{ }^{2-}$ & 0.368 & -0.161 & 0.084 & 0.324 & -0.199 & -0.199 \\
\hline
\end{tabular}

Explanations: $\mathrm{CO}_{3}{ }^{2-}$ - carbonates, Corg-organic carbon content, $\mathrm{C}_{\mathrm{HA}}: \mathrm{C}_{\mathrm{FA}}$ - carbon of humic acids to carbon of fulvic acids, $\mathrm{Q}_{\mathrm{HS}}$ - colour quotient of humic substances, $\mathrm{Q}_{\mathrm{Ha}}$ - colour quotient of humic acids, WSAm water-stable macro-aggregates, MWDs - mean weight diameter-dried sieved, MWDm - mean weight diameters of water-stable aggregates, $\mathrm{Sw}$ - index of stability, $\mathrm{K}$ - structure coefficient, $\mathrm{Kv}$ - index of vulnerability ${ }^{*} \mathrm{P}<0.05 ;{ }^{* *} \mathrm{P}<0.01 ;{ }^{* * * *} \mathrm{P}<0.001$.

As mentioned above, a very important factor for forming of favourable soil structure is soil organic matter. Several authors are interested in influence of soil organic matter on aggregate stability [Tisdall and Oades 1982, Schulten and Leinweber 2000]. Between parameters of soil structure and organic carbon in the WSA, correlation dependences were observed (Table 4). Statistically significant correlations were observed between $\mathrm{K}$ and Corg in individual size fractions of WSA. The results show that organic matter content in WSAm size fraction $3-5 \mathrm{~mm}$ had the cru-

TABLE 4. Correlations between organic carbon contents in size fractions of water-stable aggregates and parameters of soil structure stability

\begin{tabular}{lccccccc}
\hline \multicolumn{7}{c}{ Size fractions of water-stable aggregates in mm } \\
\cline { 2 - 8 } & $>5$ & $5-3$ & $3-2$ & $2-1$ & $1-0.5$ & $0.5-0.25$ & $<0.25$ \\
\hline WSA & 0,638 & 0,412 & $-0,867^{* * *}$ & $-0,641$ & $-0,319$ & $-0,254$ & $-0,108$ \\
MWDs & $-0,396$ & $0,788^{*}$ & 0,508 & $-0,748^{*}$ & 0,601 & 0,363 & $-0,108$ \\
MWDm & 0,649 & $0,720^{*}$ & $-0,757^{*}$ & $-0,917^{* *}$ & $-0,666$ & $-0,495$ & $-0,425$ \\
SW & 0,250 & $-0,024$ & $-0,491$ & $-0,072$ & 0,131 & 0,057 & 0,130 \\
K & 0,154 & $0,723^{*}$ & $-0,582$ & $-0,851^{* *}$ & $-0,846^{* *}$ & $-0,735^{*}$ & $-0,900^{* *}$ \\
Kv & $-0,542$ & $-0,856^{* *}$ & $0,791^{*}$ & $0,928^{* * *}$ & 0,656 & 0,448 & 0,650 \\
\hline
\end{tabular}

Explanations: WSAm - water-stable macro-aggregates, MWDs - mean weight diameter-dried sieved, MWDm - mean weight diameters of water-stable aggregates, $\mathrm{Sw}-$ index of stability, $\mathrm{K}-$ structure coefficient, $\mathrm{Kv}-$ index of vulnerability; ${ }^{*} \mathrm{P}<0.05 ;{ }^{* *} \mathrm{P}<0.01 ;{ }^{* * *} \mathrm{P}<0.001$ 
cial importance for aggregation processes. On the other hand, in WSA size fractions $<3 \mathrm{~mm}$ soil organic matter did not have important effect on aggregation (Table 4), which confirmed the results of Tisdall and Oades [1982] or Lado et al. [2004] as well as Six et al. [2004].

\section{CONCLUSION}

The obtained results showed on some differences in soil structure stability with dependence on soil type and management in productive vineyards. In Leptosols, the highest content of water-stable aggregates was determined. This soil type had the lowest vulnerability of soil structure as well. In Chernozems, the highest stability of soil structure was determined, on the other hand in Fluvisols soil structure had the highest vulnerability. Between rows of vine (due to mulch or sown grass) in comparison to rows of vine (intensive cultivation during vegetation of vine) more favourable soil structure was determined. In vineyards, soil structure state depends on quantity and stability of soil organic matter as well as particle size distribution. Organic matter content in WSAm size fraction 3-5 $\mathrm{mm}$ had the crucial importance for aggregation processes. It is therefore very important to give attention to quantity and quality of organic matter in productive vineyards.

\section{ACKNOWLEDGEMENT}

Project supported by the Scientific Grant Agency of the Ministry of Education of the Slovak Republic and the Slovak Academy of Sciences (No. 1/0300/11 and No. 1/0597/10).

\section{REFERENCES}

BOIX-FAYOS C., CALVO-CASES A., IMESON A.C. 2001. Influence of soil properties on the aggregation of some Mediterranean soils and the use of aggregate size and stability as land degradation indicators. Catena. 44: 47-67.

BRONICK C.J., LAL, R. 2005. Soil structure and management: a review. Geoderma. 124: 3-22.

DZIADOWIEC H., GONET S.S. 1999. Oznaczanie skladu frakcyjnego materii organicznej gleb metoda Kononowej i Bielcikowej. [In:] Przewodnik metodyczny do badań materii organicznej gleb, 1999, 120: 31-34.

GREENLAND D.J., RIMMER D., PAYNE D. 1975. Determination of the structural stability class of English and Welsh soil, using a water coherence test. J. Soil Sci. 26, 2: 294-303.

HRAŠKO J., ČERVENKA L., FACEK Z., KOMÁR J., NĚMĚČEK J., POSPÍŠIL J., SIROVÝ V. 1962. Rozbory pôd. Slovenské vydavatel'stvo pôdohospodárskej literatúry, Bratislava: $334 \mathrm{pp}$.
JARECKI M., LAL R. 2003. Crop management for soil carbon sequestration. Crit. Rev. Plant Sci. 22: 1-32.

KARLEN D.L., WOLLENHAUPT N.C., ERBACH D.C., BERRY E.C., SWAN J.B., EASH N.S., JORDAHL J.L. 1994. Long-term tillage effects on soil quality. Soil Tillage Res. $\mathbf{3 2}$ : 313-327.

KAY B.D. 1998. Soil structure and organic carbon: A review. [In:] Lal, R., Kimble, J.M., Follett, R.F., Stewart, B.A. (eds). Soil Processes and the Carbon Cycle. CRC Press, Boca Raton, USA: 169-198.

LADO M., BEN-HUR M., SHAINBERG I. 2004. Soil wetting and texture effects on aggregate stability, seal formation, and erosion. Soil Sci. Soc. Am. J. 68: 1992-1999.

LAYTON J.B., SKIDMORE E.L., THOMPSON C.A. 1993. Winter-associated changes in drysoil aggregation as influenced by management. Soil Sci. Soc. Am. J. 57: 1568-1572.

SCHULTEN H.R., LEINWEBER P. 2000. New insights into organic-mineral particles: composition, properties and models of molecular structure. Biol. Fertil. Soils. 30: 399-432.

ŠIMANSKÝ V., TOBIAŠOVÁ E. 2008. Distribúcia uhlíka vo vodoodolných agregátoch v závislosti od spôsobov obrábania a hnojenia pôdy. [In:] Šuplerová, J., Hrnčiarová, T. (eds). Ochrana a manažment pol’nohospodárskej krajiny. Ústav krajinnej ekológie SAV, Bratislava: 96-102.

SISÁK P. 1994. Štúdium vplyvu rôznych sústav hospodárenia na mikroagregátové zloženie a vodoodolnost' štruktúrných agregátov hnedozeme. [In:] Hanes, J., Mucha, V., Libant, V. (eds). Nové poznatky zvyšovania produkčnej schopnosti pôd. VŠP a VÚPÚ, Nitra: 53-56.

SIX J., BOSSUYT H., D.E., GRYZE S., DENEF K. 2004. A history of research on the link between (micro)aggregates, soil biota, and soil organic matter dynamics. Soil Tillage Res. 79: 7-31.

TISDALL J.M., OADES J.M. 1982. Organic matter and waterstable aggregates in soils. J. Soil Sci. 33: 141-163.

TOBIAŠOVÁ E. 2010. Pôdna organická hmota ako indikátor kvality ekosystémov. SPU, Nitra: 107 pp.

TOBIAŠOVÁ E. 2011. The effect of organic matter on the structure of soils of different land uses. Soil \& Tillage Res. doi:10.1016/j.still.2011.05.003.

TOBIAŠOVÁ E., HORVÁTOVÁ M. 2010. Stabilné frakcie humusových látok a mikroagregátové zloženie černozeme. [In:] Kobza J. (ed). Zb. prednášok z VIII. zjazdu Slovenskej spoločnosti pre pol’nohospodárske, lesnícke, potravinárske a veterinárne vedy pri SAV v Bratislave. VUPOP, Bratislava: 38-43.

TOBIAŠOVÁ E., ŠIMANSKÝ V. 2009. Kvantifikácia pôdnych vlastností a ich vzájomných vztahov ovplyvnených antropickou činnost'ou. SPU, Nitra: 113 pp.

VALLA M., KOZÁK J., ONDRÁČEK V. 2000. Vulnerability of aggregates separated from selected anthorsols developed on reclaimed dumpsites. Rostl. Vyr. 46: 563-568.

ZAUJEC A., ŠIMANSKÝ V. 2006. Vplyv biostimulátorov rozkladu rastlinných zvyškov na pôdnu štruktúru a organickú hmotu pôdy. SPU, Nitra: 112 pp.

Doc. Ing. Vladimír Šimanský, PhD.,

Department of Soil Science,

Slovak University of Agriculture,

Tr. A. Hlinku 2, 94976 Nitra,

Vladimir.Simansky@uniag.sk 